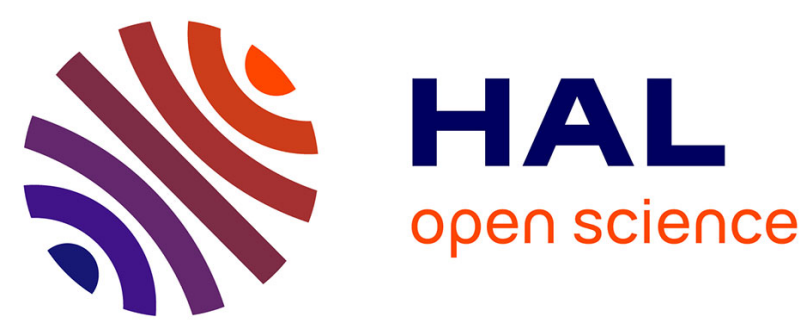

\title{
Relationships between water supply leaf area development and survival, and production in sunflower (helianthus annuus. L.)
}

André Merrien, Rene Blanchet, N. Gelfi

\section{- To cite this version:}

André Merrien, Rene Blanchet, N. Gelfi. Relationships between water supply leaf area development and survival, and production in sunflower (helianthus annuus. L.). Agronomie, 1981, 1 (10), pp.917922. hal-02727738

\section{HAL Id: hal-02727738 \\ https://hal.inrae.fr/hal-02727738}

Submitted on 2 Jun 2020

HAL is a multi-disciplinary open access archive for the deposit and dissemination of scientific research documents, whether they are published or not. The documents may come from teaching and research institutions in France or abroad, or from public or private research centers.
L'archive ouverte pluridisciplinaire HAL, est destinée au dépôt et à la diffusion de documents scientifiques de niveau recherche, publiés ou non, émanant des établissements d'enseignement et de recherche français ou étrangers, des laboratoires publics ou privés. 


\title{
Relationships between water supply, leaf area development and survival, and production in sunflower (Helianthus annuus L.)
}

\author{
André MERRIEN(*), Robert BLANCHET(**) \& Noël GELFI(**) \\ with the collaboration of Julien LAURENT(*) \\ $\left(^{*}\right)$ Centre Technique Interprofessionnel des Oléagineux Métropolitains (C.E.T.I.O.M.), Service Etudes et \\ Recherches. \\ (**) I.N.R.A., Centre de Recherches de Toulouse, Common address: Station d'Agronomie, BP 12, F 31320 \\ Castanet Tolosan.
}

SUMMARY
Sunflower,
Watersupply,
Leaf area,
Leaf area duration,
Yield,
Net assimilation.

Trying to understand the relationships between water supply, leaf area and production of two hybrids of sunflower, a pot experiment was realized with different water supplies: maximum transpiration T.M. of plants, or various fractions of T.M. Those stresses were applied either at the beginning of growth, or at early flowering only (fig. 1). The evolutions of the leaf areas, the leaf area durations (L.A.D.), the total dry matter (T.D.M.) and grain productions were controlled.

The leaf areas, the L.A.D. and T.D.M. or grain productions are functions of water supplies (fig. 2, 3, 4). But

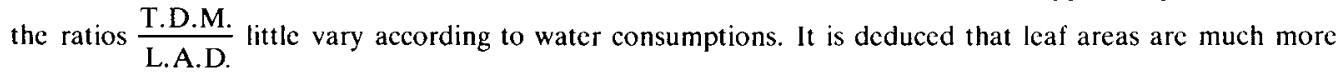
determined by water stresses than net assimilation rates of leaves in those conditions ; the same facts were observed by short-term measures of photosynthesis and transpiration (fig. 5). In those drought conditions, leaf survival appears to be an essential character, which shows some differences between the two hybrids observed (fig. 6).

\section{RÉSUMÉ \\ Tournesol \\ Alimentation hydrique, \\ Surface foliaire, \\ Durée de surface foliaire, \\ Rendement, \\ Assimilation nette.}

\begin{abstract}
Interactions entre l'alimentation en eau, le développement et la survie du feuillage, et la production chez le tournesol (Helianthus annuus L.)

Pour tenter de comprendre les relations entre l'alimentation hydrique, la surface folaire et la production de deux cultivars hybrides de tournesol, une expérimentation a été réalisée en vases de végétation avec différentes alimentations hydriques : transpiration maximale des plantes, ou diverses fractions de celle-ci ; ces contraintes hydriques étaient appliquées soit dès le début de la croissance, soit seulement à partir du début de la floraison (fig. 1). L'évolution des surfaces foliaires et les durées des surfaces foliaires (D.S.F.) ont été mesurées ainsi que les productions de matière sèche totale (M.S.T.) et de graines.

Les surfaces foliaires et les D.S.F. varient proportionnellement aux quantités d'eau fournies ainsi que lcs productions de M.S.T. et de graines (fig. 2, 3, 4). Par contre, le rapport $\frac{\text { M.S. produite }}{\text { D.S.F. }}$ varie peu selon les consommations d'eau. On en déduit, dans ces conditions expérimentales, que les contraintes hydriques conditionnent beaucoup plus les surfaces foliaires elles-mêmes que l'activité assimilatrice des feuilles; ce phénomène a été de même observé au cours de mesures instantanées de photosynthèse et de transpiration (fig. 5). Dans ces conditions de sécheresse, la survie des feuilles apparaît comme un caractère essentiel, qui présente cependant des différences entre les deux cultivars observés (fig. 6 ).
\end{abstract}

\section{INTRODUCTION}

Although the sunflower is able to grow in rather dry conditions, its water consumption is high when water availability is large, fulfilling its real maximum evapotranspiration (or E.T.R.M.) (MARTY et al., 1972 ; PUECH \& HERNANDEZ, 1973 ; DOWNES, 1974).
The period during which its drought-susceptibility is the greatest takes place about twenty days on both sides of flowering (RoBELIN, 1967 ; PIRJOL et al., 1972 ; MURIEL \& Downes, 1974 ; SipOS \& Paltineanu, 1975). The water supply after flowering also influences production (ALESSI $e t$ al., 1977).

One of the greatest repercussions of an inadequate water 
supply on the plant structure is the reduction of the leaf area (ECKART et al., 1971 ; PIRJOL, 1974). If we can often find a positive correlation between leaf area and grain production (MURIEL \& DOWNES, 1974), the modalities of this influence are still not well known, the activity of the upper leaves being able to make up for the lack of the lower ones (VREbalov, 1972; Rodriguez PEREIRA, 1974). The "leaf resistance to senescence" and, by this way, the leaf area duration is a very important yield determinant (BLANCHET et al., 1980).

On the physiological aspects, in case of water stress, the stomatal opening is reduced as well as the transpiration (per leaf area unit) and the photosynthetic activity; this decrease can persist after the disappearing of the stress (BOYER, 1971). Howewer, the rate of photosynthesis can be less affected than transpiration (RAWSON \& CONSTABLE, 1980).

The production of total dry matter and grain is not as well correlated with the water supply than in other species like maize or sorghum (BLANCHET et al., 1974). We can wonder whether a water supply satisfying the E.T.R.M. does not induce some wastage, because of the high transpiration per leaf area unit.

This high consumption leads to a low water use efficiency $\left(=\right.$ Ratio $\left.\frac{\text { Net photosynthesis }}{\text { Transpiration per leaf area unit }}\right)$; the harvest index $\left(=\right.$ Ratio $\left.\frac{\text { Grain dry matter }}{\text { Total dry matter }}\right)$ is also low (MARTY et al., 1975).

We have tried to explore some ways of a better drought adaptation, and firstly to know the relationships between the water supply, the leaf area development and survival, and the production. Therefore we realized an experiment in vegetation vessels with different water supplies leading to different vegetative developments.

So that the influence of the water supply could be studied not only on the leaf assimilation but also on the leaf area itself, known either through the maximum value measured at the flowering stage, or through the leaf area duration. The consequences upon the final productions were analysed (grain production or total dry matter).

\section{EXPERIMENTAL METHODS}

\section{A. Experimental protocol}

Two hybrids were chosen ("Relax", a french c.v., and "Mirasol", an american one), grown in vegetation vessels holding two plants each, in a natural atmosphere (under a wirenetting shelter), so to obtain an eight plants per squaremetre settlement.

The water supplies were as following (cf. fig. 1) :

- Only two supplies until the "beginning of flowering" stage, the first one satisfying the maximum transpiration (T.M.) of the standard ("Relax"), the other one bringing only 50 p. 100 of this T.M. to the plants in order to limit their vegetative growth and leaf area.

- From this stage, introduction of water stresses as following modalities:

- On one hand, a severe decrease of water supply from 100 p. 100 of the T.M. down to 50 p. 100 (treatment $B$ ) or to 30 p. 100 (treatment $C$ ) or from 50 p. 100 of the T.M. down

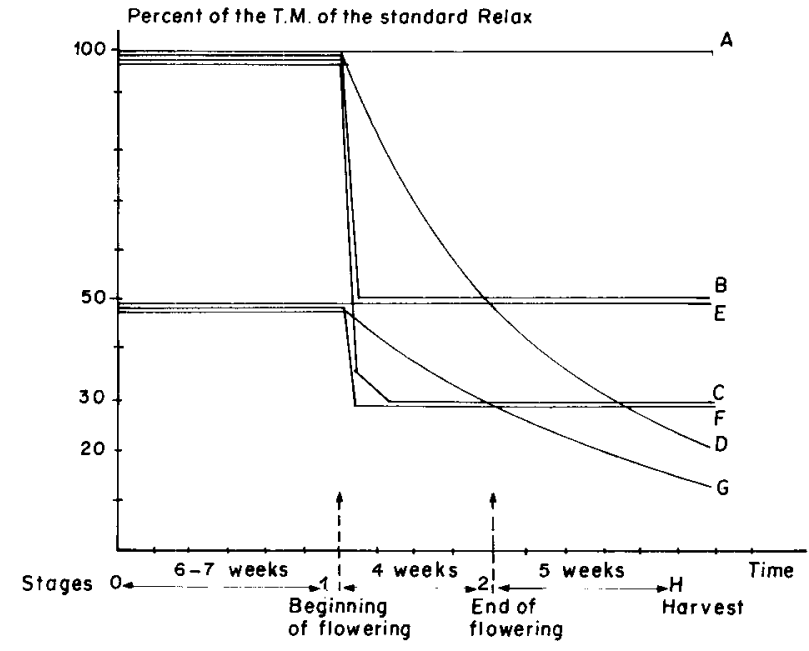

Figure 1

Diagram of the water supply during the vegetative cycle. Diagramme d'alimentation hydrique au cours du cycle végétatif.

to 30 p. 100 of T.M. (treatment F). These kinds of stresses were selected to reduce the vegetative organs by inducing some leaf senescence, and selectively to penalize the critical period for each treatment.

- On the other hand, a slow decrease of water supply so as to induce a continue under-need water supply, this reduction going either from 100 p. 100 of T.M. down to about 20 p. 100 of T.M. (treatment $D$ ), either from 50 p. 100 of T.M. down to about 10 p. 100 T.M. (treatment $G$ ).

From each primitive supply, a standard was preserved, either at 100 p. 100 of T.M. (treatment $A$ ) or at 50 p. 100 (treatment $E$ ).

In each treatment, one vessel has been amounted at the beginning of flowering (before the beginning of the stresses), another one at the end of flowering. Three other vessels have been led until harvesting, with an automatic supply like the seven ways described before.

\section{B. Main controls}

On each sampling, the water consumption, the dry matter production and the leaf areas were noted. Those were precisely measured through a photoelectric-cell apparatus ; in addition, we observed weekly the foliage characters, especially senescence and death of leaves. So we have been able to know, by plotting, the leaf area durations (L.A.D.), representing the presences of the leaf areas through the time :

$$
\text { L.A.D. }=f_{(t)} \text { S(t)dt } \quad \text { (WATSON, 1971) }
$$

At maturity, we noted also the weight of 1000 seeds and analysed their oil content.

During the cycle, tests of photosynthetic activity were carried out through SHIMSHI's technics (1969) : short pulses $(20 \mathrm{sec})$ of air containing ${ }^{14} \mathrm{CO}_{2}$ are applied to circular leaf areas of $1 \mathrm{~cm}^{2}$, enclosed in a miniature chamber, and the samples are immediately refrigerated. Their radioactivity allows to compare the relative photosynthetic activities of homologous leaves in the various treatments. As previously discussed (GELFI, 1975), these measures are used here as comparative tests.

The permeability of the sunflower leaves in measured by 
a SHImshi's apparatus (1978). Air under pressure of $200 \mathrm{~mm} \mathrm{Hg}$ is led through two flow resistances in series: one is a known resistance (in the apparatus), the other, is the resistance of the leaf to be measured. The pressure drops along the flow path are linearly proportional to the resistances. By reading the pressure drops and after calibration, we can know the leaf permeability, measured in air volume $\left(\mathrm{cm}^{3}\right)$ per leaf area $\left(\mathrm{cm}^{2}\right)$ per time (min) per pressure differential $(\mathrm{mm} \mathrm{Hg})$. The permeability can be measured from $1 \mathrm{~cm} \mathrm{~min}$ m $^{-1}(\mathrm{~mm} \mathrm{Hg})^{-1}$ (low permeability) to $5 \mathrm{~cm} \mathrm{~min}^{-1}(\mathrm{~mm} \mathrm{Hg})^{-1}$ (high permeability).

\section{RESULTS}

\section{A. Main relationships between water consumption, leaf area and production}

The figure 2 sums up the main results obtained : the leaf area (measured here at the end of flowering) and the grain production are narrowly correlated on basis of the water supply at the harvest ; both of them linearly increase with the water consumption, with high correlations ( $r$ respectively 0,90 and 0,93 ). This graph reveals no differences between the two hybrids «Relax» and «Mirasol».

The elaboration or survival of the leaf areas, and furthermore the productions, straightly depend on these water supplies as indicated by figures 3 and 4 . On figure 3, leaf area durations (L.A.D) are plotted as functions of water consumptions, and show a linear variation with a high correlation $(r=0,94)$. It is howewer interesting to note that treatment $\mathrm{D}$, in spite of a water consumption comparable to treatments $C$ and E, presents a better total L.A.D. ; this is

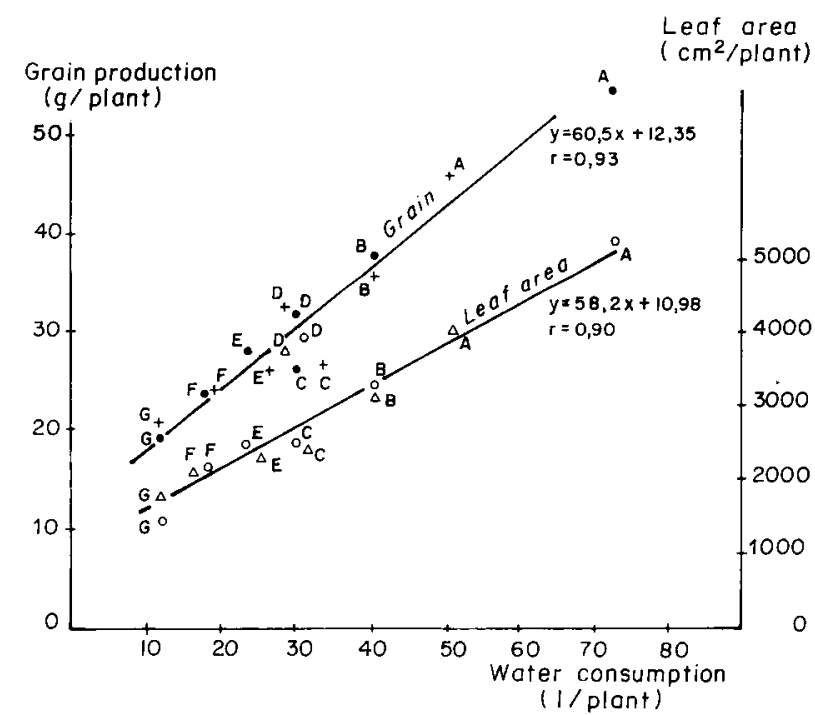

Figure 2

Relationships between water consumption, leaf area at the end of flowering and grain production (2 varieties -7 treatments).

Interactions entre l'eau consommée, la surface foliaire à la fin de la floraison et la production de grain (2 variétés -7 traitements).

- Grain "Mirasol"

+ Grain "Relax "

Leaf area "Mirasol"

$\triangle$ Leaf area "Relax"

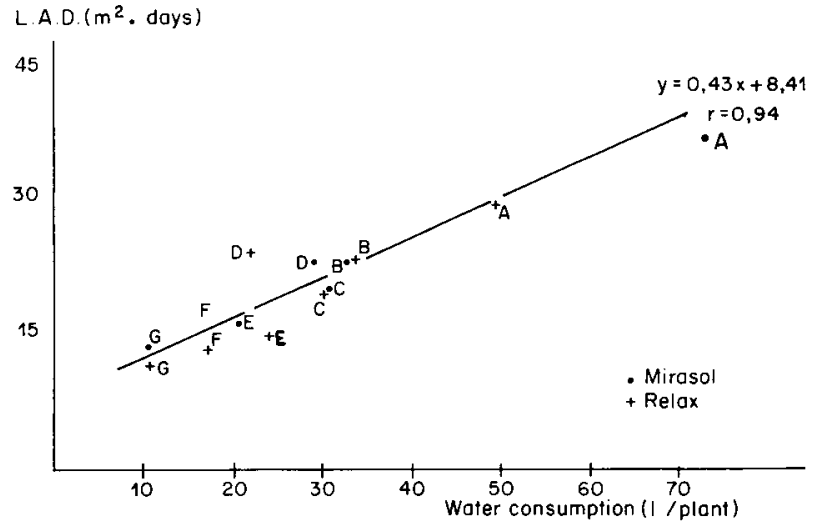

Figure 3

Relation between the leaf area duration during the whole vegetative cycle and the water consumption.

Relation entre la durée de vie du feuillage au cours de l'ensemble du cycle végétatif et l'eau consommée.

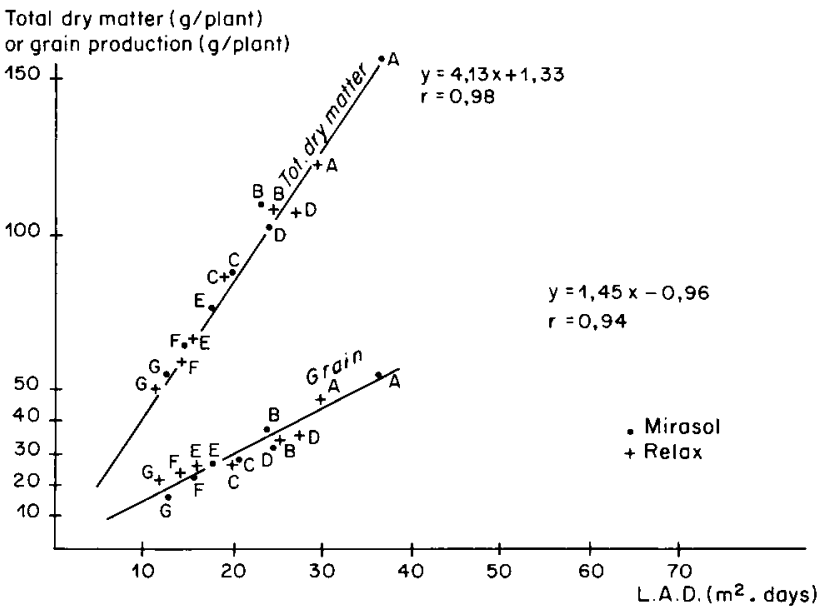

Figure 4

Relation between the productions (total dry matter or grain) on the basis of the L.A.D.

Relation entre les productions (matière sèche totale ou grain) et la D.S.F

probably due to the slower progression of the stress in $D$ (fig. 1), and we shall discuss that below.

On figure 4 , the total dry matter and grain productions show linear variations as functions of L.A.D., with very high correlation $(r=0,98$ and 0,94$)$. Therefore, those productions were essentially determined by the extend and duration of the leaf areas (themselves governed by the water supplies, fig. 2 and 3 ) and all those leaf areas worked about in the same manners, without any great differences according to the water treatments. This fact could appear surprising, knowing the influence of water stress on stomatal behaviour and $\mathrm{CO}_{2}$ assimilation. But RAwSON \& CONSTABLE (1980) and RAWSON et al., (1980) demonstrated that net assimilation can be little alterated in sunflower at low water potentials, in plants growing at such low potentials, and adapted to water stresses through several ways (stomatal apparatus, gas exchanges).

In our short-time observations, we noticed the same facts, as indicated by figure $5:$ in spite of low stomatal opening and transpiration, stressed plants $D$ and $G$ revealed $\mathrm{CO}_{2}$ fixations rather close to those of the T.M. treatment $A$. Perhaps could we understand these facts in remembering 

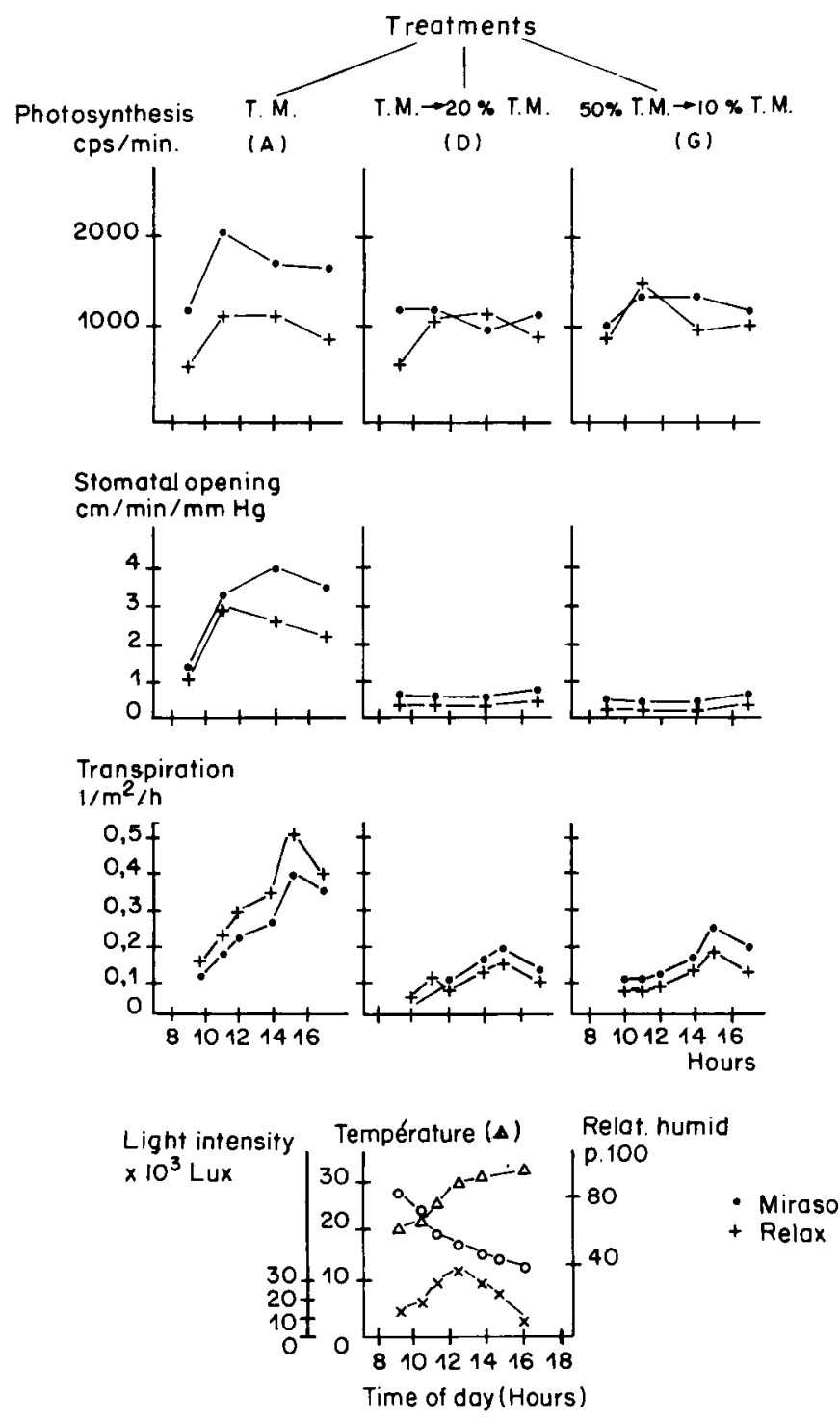

Figure 5

Leaf behaviour of two sunflower cultivars ("Mirasol" and "Relax") appreciated througth the photosynthesis, the stomatal opening and the transpiration under three water supplies.

Comportement foliaire de deux cultivars de tournesol ( Mirasol» et "Relax") apprécié par la photosynthèse, l'ouverture stomatique et la transpiration sous 3 régimes hydriques.

that the sunflower leaves have a particularly high permeability to gas (BLANCHET et al., 1978), and we can think that internal resistances to $\mathrm{CO}_{2}$ assimilation are more limiting on photosynthesis rates than the stomatal ones, in a large range of stomatal opening.

\section{B. Detail of the influence of water stresses on leaf area and production in the various treatments}

These results are indicated by table 1 , for the three stages (vegetative, flowering, grain filling) and total cycle, for the cv. "Relax"; the behaviour of "Mirasol" was almost similar.

During the first period, the plants developed their leaf areas according to the two water supplies (W.C.), with a large difference between these two supplies. The transpiration by unit of leaf area (W.C./L.A.D.) was about 25 p. 100 lower in the stressed plants $E, F, G$, but the ratios
T.D.M./L.A.D. were quite similar $(53,5 / 5,1$ and $31,5 / 3,0)$. The height of the stressed plants was reduced by 50 p. 100 .

In the second phase, the leaf area strongly regressed in $C$, and to a smaller extent in B and G, mainly at the end of the period (larger differences in leaf areas at that time than in L.A.D.) ; D was little affected. In this period of completely established leaf area and probably by an auto-shading effect, the ratios W.C./L.A.D. were smaller than in the two other phases of respective development and regression of the foliage ; these ratios do not show very large variations, reflecting the adjustment of the foliar apparatus to the available water. The increases of T.D.M. were mainly affected in the smaller water supplies $F$ and $G$.

During the grain filling period, the previous adjustments of leaf areas led to comparable W.C./L.A.D. ratios in A, B, $\mathrm{C}$ and $\mathrm{E}$; on the contrary, the same ratios were very low in $D, G$ and even $F$, where an abundant senescence then occurred. At this stage, oil synthesis in seeds is the predominant character, and its energy requirement is high (PENNING DE VRIES, 1975). Then, it is not surprising to see no marked increased in T.D.M. except in A (no water stress, highest yield), but often decreases of T.D.M., especially in C. As indicated by the low grain production, harvest index and water use efficiency, this treatment $\mathrm{C}$, characterized by a good vegetative development followed by a sharp stress inducing an abundant senescence of leaves, was the most injurious to plants. With a rather lower total water consumption and the same vegetative development, the slow and progressive stress of treatment $\mathrm{D}$, keeping alive the majority of leaves, gave much better results;

Relox T.M. (A)

Mirasol T.M. (A)
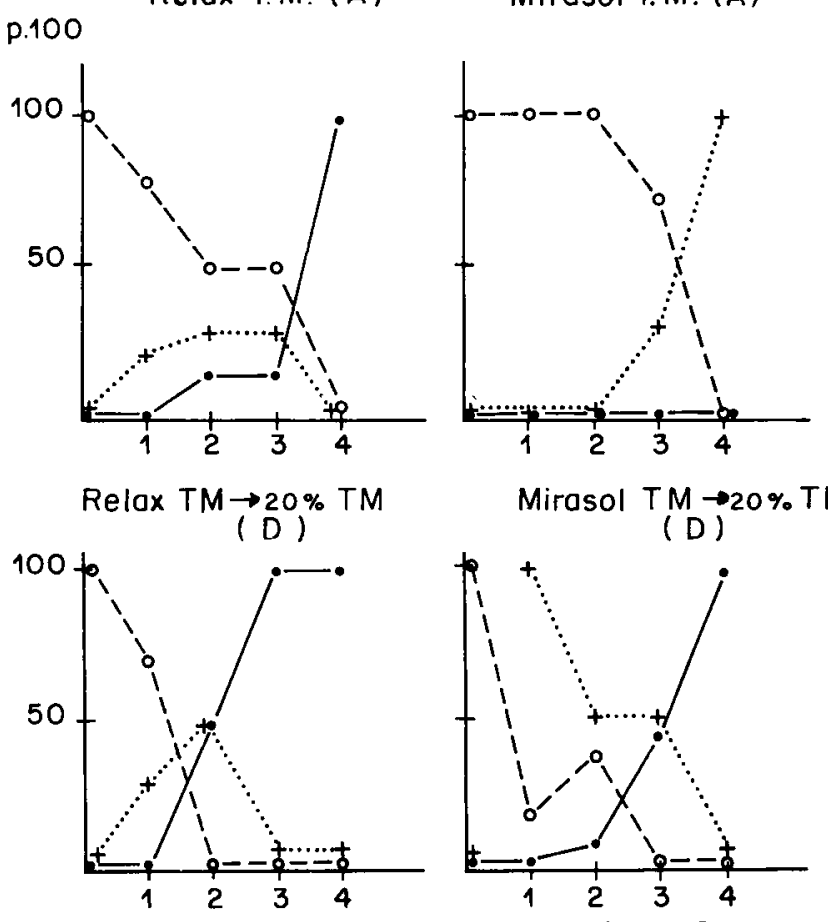

Mirasol TM $\rightarrow 20 \%$ TM

(D)

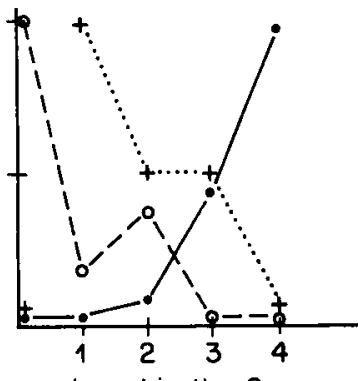

$0---0 \%$ of the leaf area alive Level in the Canopy

$+\cdots \cdots+\%$ of the leaf area senescent $\quad(1) \rightarrow$ The top

$\longrightarrow \%$ of the leaf area dead

(4) $\rightarrow$ The base

Figure 6

Evolution of senescence under two water supplies (treat. A and treat. $D-c f$. fig. 1). Differences between the two cultivars "Relax" and "Mirasol" at the end of flowering.

Evolution de la sénescence sous deux régimes hydriques (trait. A. et trait. $D-c f$. fig. 1). Différences entre les deux cultivars "Relax "Mirasol » à la fin-floraison. 
Table 1

Main characters of water consumption, leaf development and survival, and production per plant on cv. "Relax"

Principaux caractères de la consommation en eau, du développement et de la survie du feuillage et de la production, par plante, chez le cv. "Relax"

\begin{tabular}{|c|c|c|c|c|c|c|c|}
\hline WATER TREATMENTS & A & B & $\mathrm{C}$ & $\mathrm{D}$ & $\mathrm{E}$ & $\mathrm{F}$ & G \\
\hline \multicolumn{8}{|c|}{$\begin{array}{l}\text { 1st phase (vegetative) : from emergence to beginning } \\
\text { of flowering, April } 20 \text {-June } 23\end{array}$} \\
\hline Water consumption, 1 & \multicolumn{4}{|c|}{11,6} & \multicolumn{3}{|c|}{5,2} \\
\hline Height, $\mathrm{cm}$ & \multicolumn{4}{|c|}{166} & \multicolumn{3}{|c|}{83} \\
\hline Leaf area at the end of the period, $\mathrm{m}^{2}$ & \multicolumn{4}{|c|}{0,36} & \multicolumn{3}{|c|}{0,21} \\
\hline L.A.D., $\mathrm{m}^{2}$. days & \multirow{2}{*}{\multicolumn{4}{|c|}{$\begin{array}{l}5,1 \\
2,27\end{array}$}} & \multicolumn{3}{|c|}{3,0} \\
\hline Water cons./L.A.D. & & & & & \multirow{2}{*}{\multicolumn{3}{|c|}{$\begin{array}{l}1,73 \\
31,5\end{array}$}} \\
\hline Total dry matter & \multicolumn{4}{|c|}{53,5} & & & \\
\hline \multicolumn{8}{|c|}{$\begin{array}{l}\text { 2nd phase (flowering) : from beginning of flowering, } \\
\text { to petals failure, June } 23-\mathrm{July} 23 \text { : }\end{array}$} \\
\hline Water consumption, 1 & 14,8 & 9,3 & 7,5 & 10,2 & 9,0 & 4,8 & 3,9 \\
\hline Leaf area at the end of the period, $\mathrm{m}^{2}$ & 0,42 & 0,28 & 0,22 & 0,35 & 0,22 & 0,20 & 0,17 \\
\hline L.A.D., $\mathrm{m}^{2}$. days & 13,7 & 10,9 & 9,4 & 12,0 & 7,5 & 6,9 & 6 \\
\hline Water cons./L.A.D. & 1,08 & 0,85 & 0,80 & 0,85 & 1,20 & 0,70 & 0,65 \\
\hline Increase of T.D.M., g & 50 & 49 & 48 & 47 & 39,5 & 30 & 27,5 \\
\hline \multicolumn{8}{|c|}{$\begin{array}{l}\text { 3rd phase (grains filling): from petal failure to } \\
\text { maturity, July } 23-\text { September } 15:\end{array}$} \\
\hline Water consumption, 1 & 24,6 & 14,8 & 11,6 & 5,5 & 10,7 & 6,3 & 2,8 \\
\hline L.A.D., $\mathrm{m}^{2}$. days & 10,3 & 6,6 & 4,7 & 8,1 & 5,1 & 4,7 & 3,4 \\
\hline Water cons./L.A.D. & 2,39 & 2,25 & 2,47 & 0,68 & 2,10 & 1,34 & 0,85 \\
\hline Increase of T.D.M., g & $+17,8$ & $-1,0$ & $-19,1$ & $-0,5$ & $-3,0$ & $+0,8$ & $-0,8$ \\
\hline \multicolumn{8}{|l|}{ Total cycle: } \\
\hline Water consumption, 1 & $51,0(\mathrm{a})$ & $34,9(\mathrm{~b})$ & $30,8(b c)$ & $27,3(\mathrm{bc})$ & $24,9(\mathrm{c})$ & $16,4(d)$ & $11,9(d)$ \\
\hline L.A.D., $\mathrm{m}^{2}$. days & 29,1 & 22,7 & 19,3 & 25,3 & 15,7 & 14,6 & 12,4 \\
\hline T.D.M., g & $121,3(\mathrm{a})$ & $101,5(a b)$ & $82,4(\mathrm{bc})$ & $101,0(a b)$ & $68,0(b c)$ & $62,3(\mathrm{c})$ & $58,2(\mathrm{c})$ \\
\hline Grain, $\mathrm{g}$ & $46,7(a)$ & $31,4(\mathrm{~b})$ & $23,4(\mathrm{c})$ & $31,4(\mathrm{~b})$ & $24,9(\mathrm{c})$ & $21,8(\mathrm{c})$ & $21,4(\mathrm{c})$ \\
\hline Weight of 1000 seeds, $g$ & $55,2(a)$ & $48,4(\mathrm{~b})$ & $41,7(\mathrm{c})$ & $49,6(b)$ & $36,4(c)$ & $32,7(\mathrm{c})$ & $35,4(c)$ \\
\hline Oil content, $\%$ of seeds & $48,1(a)$ & 45,4 (a) & $46,1(a)$ & 41,2 (b) & $39,4(\mathrm{~b})$ & $40,0(\mathrm{~b})$ & $40,8(\mathrm{~b})$ \\
\hline Grain/T.D.M. & 0,38 & 0,31 & 0,28 & 0,31 & 0,37 & 0,35 & 0,38 \\
\hline Grain/Water cons. (W.U.E.) & 0,84 & 0,90 & 0,76 & 1,15 & 1,0 & 1,33 & 1,80 \\
\hline
\end{tabular}

L.A.D. = Leaf area duration ; T.D.M. = Total Dry Matter ; W.U.E. $=$ Water use efficiency

A, B... G : see figure $1 ; a, b, c:$ statistic signification DUNCAN test, $5 \%$

nevertheless, the low oil content of the seeds reveals the suffering at the end of the cycle.

According to their conditions, the small-sized plants $\mathrm{E}, \mathrm{F}$, $G$ gave rather correct yields, with higher harvest index than the taller ones, and increasing water use efficiencies (W.U.E.) ; but the poor weights and oil contents of seeds reflect the suffering. Probably they beneficiated of progressive adaptation to drought, especially $G$ with its very high W.U.E.

\section{DISCUSSION AND CONCLUSIONS}

These results mainly show the large capacity of sunflower to adjust its leaf area to the water availabilities, either by the size of leaves when they develop under stress (the number of leaves was still constant for each variety in our experiments), or by senescence and foliage regression when the stress occurs after the end of the vegetative phase. When the water-status of plants has reached a kind of steady-state, the gas exchanges of the leaves (transpiration, photosynthesis) do not vary in a very large scale, leading to the relation of figures $2,3,4$. Howewer, a gradually increasing water stress brings on a higher water use efficiency, accompanied by a non-negligible seed production (treatment $G$ ). This explains that sunflower can be grown in rather arid zones, with low but still significant and not too irregular yields.

For this species, our experiments confirm the conception (BOYER, 1970 ; HSIAO et al., 1976 ; RAWSON et al., 1980) that water stress affects the whole foliage structure, and by this way the grain production, more than the assimilation of the unit of leaf area. Then, the leaf resistance to senescence can be of great agronomical importance, and on this subject we noted some difference between our two cultivars, as indicated by figure 6 : both leaf senescence and death appear a little earlier on "Relax" than on "Mirasol", and we previously noted in field larger differences among varieties (BLANCHET et al., 1980). As noted by VREBALOW (1972) \& CONNOR \& CAWOOD (1978), a good leaf survival during the seed-filling period is of great importance for yield and oil content ; in our case, the difference between "Relax" and "Mirasol" was not consistent on yield, but was on oil content (averages of all treatments : 43,0 p. 100 for "Relax" and 49,4 p. 100 for "Mirasol"). The survival of the leaves of the middle of the canopy, often damaged by severe hydric stresses, is of particular interest on this point (VREBALOV, 1972) ; probably they act both by late assimilation and translocations.

The optimum vegetative size (leaf area, height) for dry conditions can also be discussed. These experiments confirm our previous results (BLANCHET \& GELFI, 1978) : if the water disponibilities are not too low during the repro- 
ductive phase (treatment B), and the stress rather progressive (D), a good vegetative apparatus is preferable, as generally found by plant breeders (KESTELOOT et al., 1978). If the stress is very strong $(F, G)$, or sudden $(C)$, a moderate vegetative development could be preferable, leading to a better water use efficiency $(F, G)$.

Finally, this study allows to better understand the relationships between water consumptions, leaf area development and survival, and production of sunflower, and shows that water supply largely induces leaf area adjustments and, by the way, yield and oil content. It also shows that a certain adaptation to drought can happen under progressive stresses, and that we have to be careful in extrapolations of results obtained on non-previously stressed plants, when we intend to predict the behaviours under stress.

Reçu le 10 mars 1981. Accepté le 26 août 1981.

\section{REFERENCES}

Alessi J., Power J. F., Zimmerman D. C., 1977. Sunflower yield and water use as influenced by planting date, population, and row spacing. Agron. J., 69, 465-469.

Blanchet R., Gelf N., 1978. Relations entre développement foliaire, transpiration et production chez le soja (cv. « Amsoy 71 » et « Hodgson»). Ann. agron., 29 (3), 223-242.

Blanchet R., Gelfi N., Merrien A., 1978. Rôle de la structure des feuilles dans la consommation d'eau du tournesol. Inf. Techniques CETIOM $\mathrm{n}^{\circ} 63$.

Blanchet R., Maertens C., Marty J. R., Puech J., 1974. Principaux facteurs déterminant la conduite et l'efficacité de l'irrigation. Agrochimica, 18, 288-307.

Blanchet R., Merrien A., Gary C., 1980. Quelques facteurs déterminant la tolérance de différents types variétaux de tournesol à une sécheresse sévère appliquée à partir de la floraison. 9th Int. Sunfl. Conf. (Malaga - Spain) (juin 1980 en cours de publication).

Boyer J. S., 1970. Leaf enlargement and metabolic rates in corn, soybean and sunflower at various leaf water potentials. Plant Physiol. 46, 233-235.

Boyer J. S., 1971. Recovery of photosynthesis in sunflower after a period of low leaf water potential. Plant Physiol. 47, 816-820.

Connor D. J., Cawood R. J., 1978. The effect of water stress on the assimilation and allocation of carbon during seed filling in sunflower. 8th Int. Sunfl. Conf., Minneapolis, U.S.A., 106-116.

Downes R. W., 1974. Environmental and physiological characteristics affecting sunflower adaptation. 6th Int. Sunfl. Conf., Bucarest, Roumanie, 197-204.

Eckardt F. E., Heim G., Methy M., Saugier B., Sauvezon R., 1971. Fonctionnement d'un écosystème au niveau de la production primaire; mesures effectuées dans une culture d'Helianthus annuus. Oecol. Plant. 6, 51-100.

Gelfi N., 1975. Influence des conditions d'alimentation hydrique et azotée sur l'efficience de l'eau et la production chez le soja (variété "Amsoy"). Thèse Université Paul-Sabatier, Toulouse, n" 315, $80 \mathrm{p}$.

Hsiao T. C., Fereres E., Acevedo E., Henderson D. W., 1976. Water stress and dynamics of growth and yield of crop plants. In "Water and plant life", Lang et al. Ed., Springer-Verlag, Berlin, 281-305.

Kesteloot L. A., Leclerq P. \& Serieys M., 1978. Recherches contribuant à la détermination des éléments permettant la différenciation entre hybrides à haut et bas rendements dans te tournesol (Helianthus annuus L.) 8th Int. Sunfl. Conf., Minneapolis, 343-347.

Marty J. R., Puech J., Decau J., Maertens C., 1972. Effets de l'irrigation sur la production et la qualité du tournesol $-5^{\circ}$ Conf. Int. Tournesol, Clermont-Ferrand, France, 46-53.
Marty J. R., Puech J., Maertens C., Blanchet R., 1975. Etude expérimentale de la réponse à l'cau de quelques grandes cultures à l'irrigation. C.R. Acad. Agric. Fr., 61, 560-575.

Muriel J. L., Downes R. W., 1974. Effect of periods of moisture stress during various phases of growth of sunflower in the greenhouse. 6th Int. Sunfl. Conf., Bucarest, Roumania, 127-132.

Penning de Vries F. N. T., 1975. Photosynthesis and productivity in different environments. Cooper Ed., Cambridge Univ. Press., 459461 .

Pirjol-Savulescu L., 1974. Variability of sunflower resistance to drought. 6th Int. Sunfl. Conf., Bucarest, Roumania, 133-144.

Pirjol-Savulescu L., Milica C. I., Vranceanu V., 1972. Etude de la résistance à la sécheresse pendant différentes phases de végétation chez le tournesol. $5^{e}$ Conf. Int. Tournesol, Clermont-Ferrand, France, 36-45.

Puech J., Hernandez M., 1973. Evapotranspiration comparée de différentes cultures et étude de quelques facteurs influençant les rythmes de consommation. Ann. agron. 24, 437-455.

Rawson H. M., Constable G. A., 1980. Carbon production of sunflower cultivars in field and controlled environments. I Photosynthesis and transpiration of leaves, stems and heads. Aust. J. Plant Physiol. 7, 555-573.

Rawson H. M., Constable G. A., Howe G. N., 1980. Carbon production of sunflower cultivar in field and controlled environments. II - Leaf growth. Aust. J. Plant Physiol. 7, 575-586.

Robelin M., 1967. Action et arrière-action de la sécheresse sur la croissance et la production du tournesol. Ann. agron. 18, 579-599. Rodriguez Pereira, 1974. Effects of artificial defoliation on components of yield in sunflower. 6th Int. Sunfl. Conf., Bucarest, Roumania, 181-188.

Shimshi D., 1969. A rapid field method of measuring photosynthesis with labelled carbon dioxide. Isr. J. Bot. 20, 381-401.

Shimshi D., 1978. A fast reading viscous flow leaf porometcr. New Phytol., 593-598.

Sipos G. H., Paltineanu R., 1975. Consumul de apa si regimul de irigare la principalele culturi agricole. Prod. veg. Cereale Plante Teh. 5, 3-9.

Vrebalov T., 1972. The role of leaves in the process of kerncl yield and oil content formation in sunflower. 5th Int. Sunfl. Conf., Clermont-Ferrand, France, 57-62.

Watson D. J., 1971. Size, structure and activity of the productive systcm of crops. Potential Crop Prod., 76-88. 